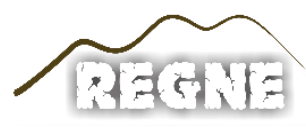

ISSN: 2447-3359
REVISTA DE GEOCIÊNCIAS DO NORDESTE

Northeast Geosciences Journal

v. $7, \mathrm{n}^{\circ} 2(2021)$

https://doi.org/10.21680/2447-3359.2021v7n2ID22049

\title{
2-D INVERSION OF MAGNETIC DATA AND GRAVITY MODELLING OF THE TRANSITION ZONE BETWEEN THE PERNAMBUCO-ALAGOAS DOMAIN AND THE NORTHERN PORTION OF THE SERGIPANO BELT (NE, BRAZIL)
}

\section{Priscilla Alvarez ${ }^{1}$; Alanna Costa Dutra ${ }^{2}$}

${ }^{1} \mathrm{MSc}$. in Geophysics, Department of Geophysics, Institute of Geosciences - UFBA, Salvador/BA, Brazil.

ORCID: https://orcid.org/0000-0002-0388-9744

E-mail: priscilla.geoph@gmail.com

${ }^{2} \mathrm{PhD}$. in Geophysics, Department of Earth Physics and Environment, Institute of Physics - UFBA, Salvador/BA, Brazil. ORCID: https://orcid.org/0000-0002-9144-5683

E-mail: alannacd@gmail.com

\begin{abstract}
Two-dimensional magnetic inversions were performed with the purpose to obtain information about the magnetic susceptibility, depth and volume of true magnetic sources located in the basement adjacent to the Sergipe-Alagoas basin, in the transition zone between the Pernambuco-Alagoas Domain and the northern portion of the Sergipano Belt (Borborema Province, NE Brazil) and to delineate its geometries. The magnetic data processing was performed to interpret geological contacts, source's edge boundaries and mapping of folds and shear zones. In the results of the magnetic inversion, a source was found in the Rio Coruripe domain between 9 and $21 \mathrm{~km}$ in depth with a magnetic susceptibility of 0.0079 (SI) and another in the PernambucoAlagoas domain between 7.5 and $9 \mathrm{~km}$ with a magnetic susceptibility of 0.0077 (SI). The basement's depth was obtained through spectral analysis, whose base was found at $37.7 \mathrm{~km}$. In addition, gravity models were created with the purpose to verify the information obtained by the magnetic inversion and spectral analysis, which was useful to understand how these sources interfere in the structure of the basement and how it affected its tectonic model.
\end{abstract}

Palavras-chave: Magnetic inversion; Gravity modelling; Sergipe-Alagoas basin.

\author{
INVERSÃO 2-D DE DADOS MAGNÉTICOS E \\ MODELAGEM GRAVIMÉTRICA DA ZONA DE \\ TRANSIÇÃOO ENTRE O DOMÍNIO PERNAMBUCO- \\ ALAGOA̧S E A PORÇÃO NORTE DA FAIXA \\ SERGIPANA (NE, BRASIL)
}

\section{Resumo}

Inversões magnéticas bi-dimensionais foram realizadas com o objetivo de obter informações sobre a susceptibilidade magnética, profundidade e volume de fontes magnéticas localizadas no embasamento adjacente à Bacia Sergipe-Alagoas, na zona de transição entre o domínio Pernambuco-Alagoas e a porção norte da Faixa Sergipana (Província Borborema, NE Brasil) e delinear suas geometrias. O processamento de dados magnéticos foi realizado para interpretar contatos geológicos, delimitações de bordas de fontes e mapear dobras e zonas de cisalhamento. Nos resultados das inversões magnéticas, uma fonte foi encontrada no domínio Rio Coruripe entre 9 e $21 \mathrm{~km}$ em profundidade, com uma susceptibilidade magnética de 0.0079 (SI), e outra no domínio Pernambuco-Alagoas entre 7.5 e $9 \mathrm{~km}$ em profundidade, com uma susceptibilidade magnética de 0.0077 (SI). A profundidade do embasamento foi obtida através de análises espectrais, cuja base foi encontrada em $37.7 \mathrm{~km}$. Além disso, modelos gravimétricos foram criados com o objetivo de verificar a informação obtida pela inversão magnética e análise espectral, o que foi útil para compreender como essas fontes interferem na estrutura do embasamento e como afeta o seu modelo tectônico.

Keywords: Inversão magnética; Modelagem gravimétrica; Bacia Sergipe-Alagoas.

INVERSIÓN 2-D DE DATOS MAGNÉTICOS Y MODELADO GRAVIMÉTRICO DE LA ZONA DE TRANSICIÓN ENTRE EL DOMINIO PERNAMBUCOALAGOAS Y LA PORCIÓN NORTE DE LA FAJA SERGIPANA (NE, BRASIL)

\section{Resumen}

Se realizaron inversiones magnéticas bidimensionales para obtener información sobre la susceptibilidad magnética, la 
profundidad y el volumen de las fuentes magnéticas ubicadas en el basamento adyacente a la cuenca Sergipe-Alagoas, en la zona de transición entre el dominio Pernambuco-Alagoas y la porción norte de la Faja Sergipana (Provincia Borborema, NE Brasil) y para delinear sus geometrías. El procesamiento de los datos magnéticos se realizó para interpretar los contactos geológicos, la delimitación de los bordes de la fuente y para mapear los pliegues y las zonas de cizalla. En los resultados de las inversiones magnéticas, se encontró una fuente en el dominio de Río Coruripe entre 9 y $21 \mathrm{~km}$ de profundidad, con una susceptibilidad magnética de 0.0079 (SI), y otra en el dominio PernambucoAlagoas entre 7.5 y $9 \mathrm{~km}$ de profundidad, con una susceptibilidad magnética de 0.0077 (SI). La profundidad del basamento se obtuvo mediante análisis espectral, cuya base se encontró en 37,7 $\mathrm{km}$. Además, se crearon modelos gravimétricos con el objetivo de verificar la información obtenida por inversión magnética y análisis espectral, lo que fue útil para comprender cómo estas fuentes interfieren con la estructura del basamento y cómo afecta su modelo tectónico.

Palabras-clave: Inversión magnética; Modelado gravimétrico; Cuenca Sergipe-Alagoas.

\section{INTRODUCTION}

The Sergipe-Alagoas basin is located at the continental margin of the Brazilian northeast region, with an area of approximately $45.000 \mathrm{~km}^{2}$ and has a good potential for oil exploration and production in ultra-deep waters, which represents high interest for the oil industry and makes important the development of researches in this area. The description of the geological context of the Sergipe-Alagoas basin has been well explained by dos Santos et al. (1998), however, subsurface models are scarce, and therefore, makes this one of the main objects of study of this research. Thus, geophysics enters as an effective tool for producing models of physical properties' distribution in the region's subsurface.

In this work, we focus on the transition zone between the Pernambuco-Alagoas (PEAL) domain and the northern portion of the Sergipano Belt, located in the southern portion of the Borborema Province (Neves et al., 2016). The Sergipano Belt is often considered to be the product of a continental collision between the PEAL Massif and the São Francisco Craton. Given the overall southward vergence of the Sergipano Belt, the São Francisco Craton should represent the lower plate whereas the
PEAL Massif would constitute the upper plate. The Macururé Complex and the low-grade to unmetamorphosed domains of the southern Sergipano Belt correspond to distal and proximal facies, respectively, of platform sediments deposited onto the passive continental margin of the São Francisco Craton. In this model, the suture zone separating the two plates would be located close to the transition zone (dos Santos et al., 1998).

In the transition zone, two magnetic sources were found, one in the Rio Coruripe Domain and another in the PernambucoAlagoas domain. These sources have significant total magnetic field and bouguer anomalies due to their high magnetic susceptibility and density contrasts, which made it possible to study it through magnetic and gravity methods.

In that way, a two-dimensional magnetic inversion and gravity modelling were performed with the purpose to obtain information about the sources' depth, volume and magnetic susceptibility contrasts. The magnetic inversion was performed using a technique developed by Stocco et al. (2009), that provides a compact inversion of the source bodies, based on the principle of Last and Kubik (1983). A spectral analysis and magnetic data processing were also performed, which allowed the interpretation of geological contacts, folds and shear zone, and contributed to the characterization of the basement adjacent to the SergipeAlagoas basin.

The gravity and magnetic measurements are important to produce a geological interpretation to understand the tectonic environment. The continental terrain boundaries were commonly recognized by contrast in all contacts and knowing the gravity and magnetic anomalies, we were able to model the crust. These models allow us to interpret the crustal domains and their tectonic relations.

\section{GEOLOGICAL SETTING}

The Sergipe-Alagoas basin has an area of $31.750 \mathrm{~km}^{2}$ in the sea portion and $12.620 \mathrm{~km}^{2}$ in the land portion and is subdivided in two sub-basins, Alagoas and Sergipe (Figure 1), where its internal limits are given by Japoatã-Penedo High (ANP, 2015). In Sergipe state, the Borborema Province is represented by the Sergipano Belt, located between the northeast limit of the São Francisco craton and the Pernambuco-Alagoas massif (dos Santos et al., 1998). The Alagoas state is located at the southern subprovince of the Borborema Province, which is limited at north by the Pernambuco lineament.

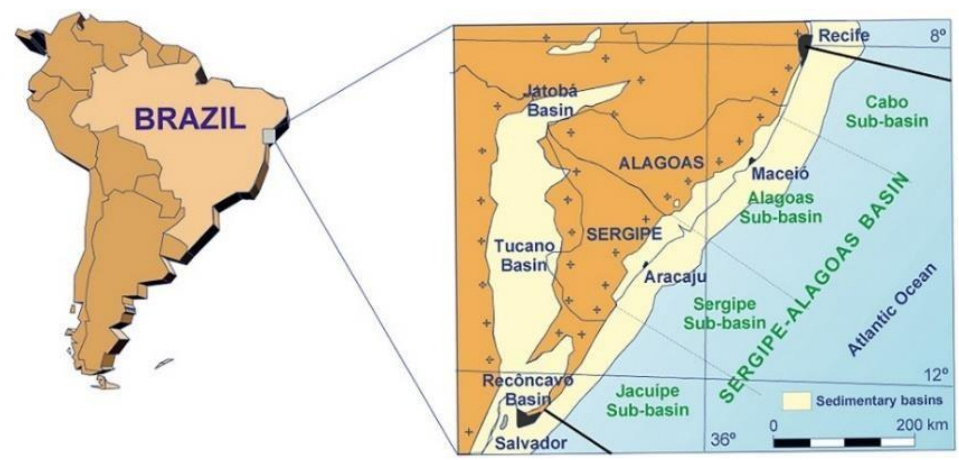

Figure 1 - Location map of the Sergipe-Alagoas basin in northeast Brazil. Source: Souza-Lima et al. (2002). 
Located on the north-central portion of Alagoas state, the Pernambuco-Alagoas domain is limited southwest by the Canindé and Marancó-Poço Redondo domains through contractional shear zones, and south-southeast by the Rio Coruripe domain through the contractional shear zone Palmeira dos Índios, with top to the north vergence (Mendes et al., 2017). The Pernambuco-Alagoas domain also contains the presence of a sinistral shear zone, which we can observe in Figure 2.b, and consists predominately of orthogneisses, supracrustal units of high grade, often migmatized (Brito Neves et al., 1982), dated of $1.577 \mathrm{Ma}$ and brazilian granitoids of varied composition.

The Sergipano Belt is composed by the Rio Coruripe, Macururé, Canindé and Marancó-Poço Redondo domains, and by the gneissic Jirau do Ponciano Dome (Figure 2.a). The northern portion of the Sergipano Belt is further subdivided into the
Canindé and Rio Coruripe domains, whose limit would be a sinistral transcurrent shear zone (Neves et al., 2016), which we are able to visualize in Figure 2.c. The Rio Coruripe domain, where one of the magnetic sources were found, is located in the central portion of Alagoas state, being limited at north by a contractional shear zone with the Pernambuco-Alagoas domain and south-southwest by the Belo Monte-Jeremoabo shear zone. It is composed by paragneisses, migmatites and metaultramafic rocks intercalated with banded iron formations, dated of $1.970 \mathrm{Ma}$ (Mendes et al., 2017), which can justify the magnetic properties of the source.

The basement adjacent to the Sergipe-Alagoas basin is formed by supracrustal rocks with granulite facies along supracrustal rocks with amphibolite facies.

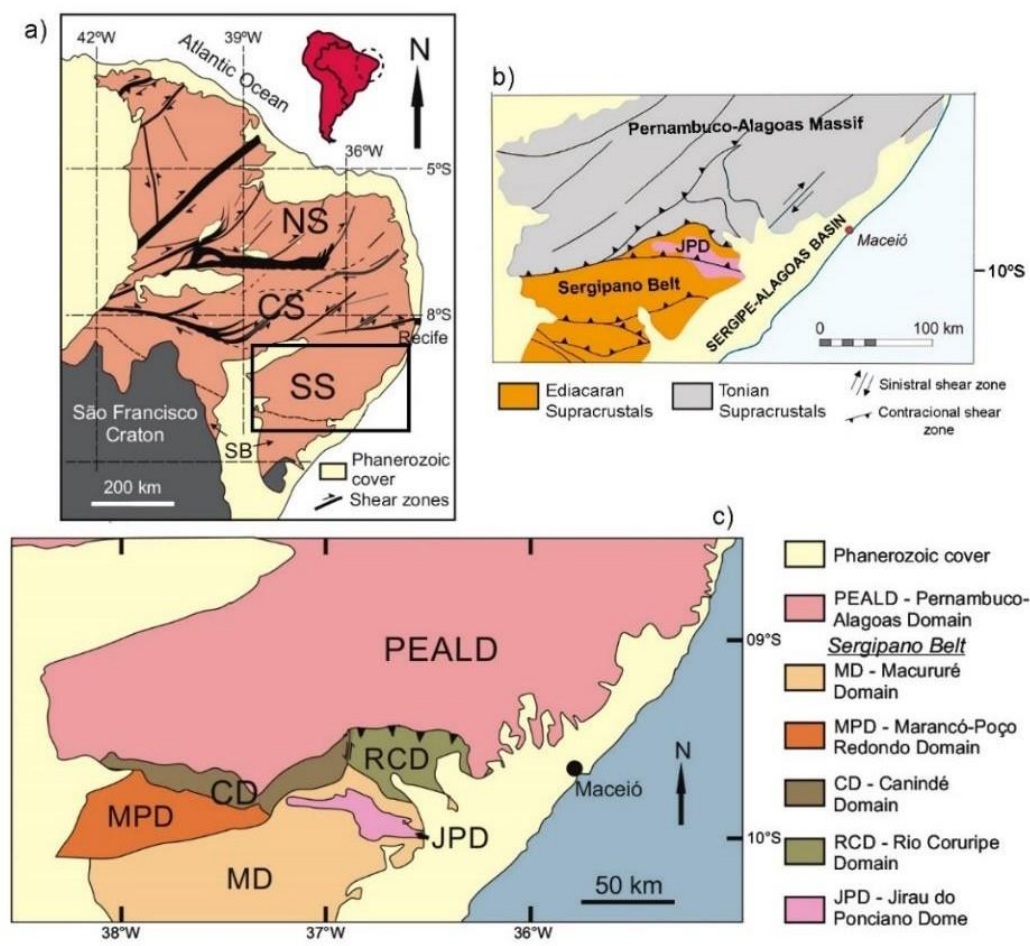

Figure 2 - Geologic map of the study area. A) Sketch showing the subdivision of the Borborema Province in Northern (NS), Central (CS) and Southern (SS) provinces. SB: Sergipano Belt. Rectangle shows location of the study area. B) Location of the Sergipe-Alagoas Basin, Pernambuco-Alagoas Massif and Sergipano Belt. Arrows and sawteeth indicate sinistral and contractional shear zones, respectively. C) Simplified geological map of the area outlined in a) showing the domain's locations. Source: Modified of Neves et al. (2016) and Lima et al. (2015).

\section{METHODOLOGY}

The database gathering involved merging numerous surveys with gravity and aeromagnetic data with highly variable specifications and quality. Integrated and corrected anomaly maps were processed and interpreted. Knowing the gravity and magnetic anomalies, it was possible to estimate upper and lower depths, magnetic lineaments, faults, blocks, lateral extensions and the width of the sources. From these results, we can produce a geological interpretation and understand the tectonic environment.

The aeromagnetic surveys have a spacing of flight lines of 500 meters oriented in the N-S direction, with flight height of 100 meters, the interval between measurements of the magnetometer of 0.1 seconds and the spectrometer 1.0 seconds.

The survey was carried out in two different blocks with different flight and tie-line directions, and data acquisition was performed perpendicular to the main structures of the surveyed area. The study area's magnetic data was generated from the pre- 
processed data, using different combinations of parameters and cell size of $1 / 4$ of the flight line.

Grids of the magnetic anomaly were generated and then, a database of each grid was created around the Sergipe-Alagoas basin, defining the area of study. The magnetic system used was an optically pumped (cesium vapor) magnetometer that was installed in a stinger extension behind the tail of the aircraft. The output from the magnetometer was sampled at 0.1 seconds to a resolution of $0.001 \mathrm{nT}$, with a noise envelope less than $0.01 \mathrm{nT}$.

The gravity data was acquired with a Scintrex CG5 and the necessary planialtimetric survey was done with a differential GPS. The data acquired in the field were georeferenced and processed, where later the gravimetric corrections were applied, interpolated and filtered. Since gravity varies from point to point over the entire earth's surface, variations with different causes overlap and are mutually mixed. When the purpose is to study gravity variation caused by differences in density, it is necessary to eliminate all other known variations (such as the ones caused by rotation and flatness of the Earth, attraction of the Moon and the Sun, variations in altitude between measurement points and effects of the crust structure and upper mantle).

The anomaly appearance depends on the dimensions, density contrasts and depth of the anomalous body. Its horizontal extension is called the apparent wavelength. In order to estimate

the regional gravimetric effect and its subsequent separation, a polynomial fit method was applied, where the surface polynomial, which best represents the regional behavior of the data, is chosen. This choice is made by analyzing the regional and residual maps, and verifying which polynomial degree best represents the anomaly. The residual Bouguer anomaly was obtained through the removal of a regional surface adjusted by Least-Squares method.

\subsection{Spectral analysis}

Usual linear transformations were applied to the gravity and magnetic data with the purpose to process changes in the amplitude and/or phase related to the set of the data. These transformations are carried out by multiplying the Fourier transform in the data set in the frequency domain. The inverse Fourier transform returns to the space domain and provides the current field to the upper level. This process is equivalent to convolving the field in the space domain by an operator (or filter). All transformations of the magnetic field work on this path.

To perform the inversion, a regional-residual separation of the magnetic data was made by upward continuation, where the removal of information is realized from a value of depth, obtained through the analysis of the shape of the radially average power spectrum $(P S)$ curve of the data, known as spectral analysis, given by Equation 1:

$$
P S(k)=C e^{-4 \pi z f},
$$

where $C$ is a constant that includes field parameters, and $f$ is frequency.
If we apply the natural logarithm on both sides of Equation 1, we obtain the inclination $(s)$ of the line $\ln (P S)$ versus $f$. Therefore, we can calculate the depth of magnetic sources through the inclination $(s)$ of the line, hence Equation 2:

$$
z(f)=\frac{s}{4 \pi}
$$

\subsection{Total Horizontal Gradient (GHT)}

Magnetic data processing was performed with the purpose to enhance features that couldn't be observed in the original data. In that way, a phase transformation called Total Horizontal Gradient (THG) was applied on a residual magnetic field anomaly data with the purpose to detect source's edge boundaries of magnetic anomalies.

The steepest horizontal gradient caused by a tabular body tends to overlap and have its maximum amplitude over the source's boundaries, and have its minimum amplitude over the center of the source. The Total Horizontal Gradient can be calculated using finite difference methods, given by Equation 3:

$$
|T H G(x, y)|=\sqrt{\left.\frac{\partial \Delta F}{(\overline{\partial x}}\right)^{2}+(\overline{\partial y})^{2}}
$$

\subsection{2-D Magnetic Inversion}

To obtain information about the magnetic susceptibility, depth and volume of the sources, a bidimensional inversion of the magnetic data was performed using a software called MAG2DATA, developed by Stocco et al. (2009) in Matlab code, that can be used to model the response of bodies with simple shape and regular geometry through magnetic profiles extracted from maps.

The code considers the subsurface as being composed of 2-D horizontal prisms orthogonal to the profiles, with a constant magnetic characteristic in each prism. The remanent magnetization effect is also incorporated by the method, as the priori information about the source.

The inversion of the magnetic data is performed in two steps: calculation of the direct problem (forward modelling) and solution of the inverse problem (inversion).

The forward modelling calculates a theoretical response of magnetic sources, assuming hypothetical volume, form and susceptibility contrasts between the source bodies and the hosting environments (Stocco et al., 2009). To model total magnetic field anomalies, considering that the targets are two-dimensional, we assume the relation in Equation 4:

$$
F=k F_{e} G,
$$

where $F$ is the total field, $k$ the susceptibility contrast, $F_{e}$ the earth's magnetic field, and $G$ is a kernel matrix given by Equation 5 to model the response of a 2-D prism: 


$$
\mathrm{G}=2\left[\cos I \sin \beta \ln \left(r_{2} r_{3} / r_{4} r_{1}\right)-\sin I\left(\emptyset_{1}-\emptyset_{2}-\emptyset_{3}+\emptyset_{4}\right)\right],
$$

where $r_{i}$ and $\emptyset_{i}$ are distances and angles shown in Figure 3, and $I$ is inclination and $\beta$ is declination (magnetic north) of the earth's magnetic field.

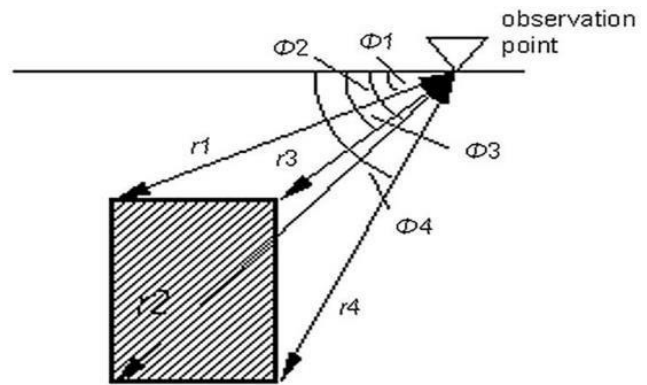

Figure 3 - Geometry of a vertical prism of finite depth extent. Source: Stocco et al. (2009).

The method of inversion is based on the principle of compact inversion (Last and Kubik, 1983) that involves minimizing the surface area of the source, which means maximizing its compactness, with the purpose to obtain the best result at each iteration. The inverse problem is solved using the weighteddamped least-squares method, given in Equation 6:

$$
v=\underset{v}{W^{-1} G^{T}} \underset{v}{\left(G W^{-1} G^{T}+W^{-1}\right)^{-1} d,}
$$

where having $m$ prisms of unknown susceptibility and $n$ measured data: $v$ is the unknown susceptibility vector, $(m \times$ $1) ; d$ the observed magnetic data set $(n \times 1) ; W_{v}$ is the susceptibility weighting matrix $(m \times m) ; W_{e}$ is the noiseweighting matrix $(n \times m) ; W_{v}$ and $W_{e}$ are diagonal matrices, where as in the Equations 7 and 8, respectively:

$$
\begin{gathered}
{\left[W_{v}^{(k-1)}\right]_{i i}^{-1}=\left[v_{i}^{(k-1)}{ }^{2}\right]+\varepsilon,} \\
W_{e}^{-1}=(N / S) \operatorname{diag} \underset{v}{\left(G W^{-1} G^{T}\right) .}
\end{gathered}
$$

where $k$ is the iteration, $\varepsilon$ the perturbation number whose value is between $10^{-13}$ e $10^{-10}$, and $N / S$ is the noise-to-signal ratio.

\subsection{Gravity Modelling}

Gravity modelling is based on the direct calculation of the gravitational field produced by a geometric shape, in which an initial model is constructed for the source body based on available geological and geophysical information, so that the anomaly generated by this model is the gravity anomaly observed. This process of parameter adjustment is performed until the calculated and observed anomalies are as similar as possible.

The gravity modelling was performed at the software GMSYS, which is based on the method of bidimensional modelling developed by Talwani et al. (1959). In this method, lithological structures are drawn in shapes of polygons and the volume of the source is obtained by the calculation of the gravitational attraction caused by each vertex of the polygon, where the density is constant in every source body.

\section{RESULTS AND DISCUSSIONS}

The aeromagnetic data used in this work were granted by CPRM (Company of Research in Mineral Resources) and to obtain the subject of interest of this study, a regional-residual separation process was required. For the magnetic data, an upward continuation was performed, where the estimated depth value used in this process was obtained through an analysis of the data's radially average powerspectrum.

The analysis was applied on polygons with $25 \mathrm{~km}^{2}, 50 \mathrm{~km}^{2}$, $100 \mathrm{~km}^{2}, 150 \mathrm{~km}^{2}$ and $200 \mathrm{~km}^{2}$ taken from the Total Magnetic Field Anomaly Map (Figure 5.a) and performed on a program in Matlab code. For each polygon, a power spectrum curve was

generated (Figure 4), where deeper sources are located at the beginning of the curve (color magenta) and shallower sources (color green) go until the Nyquist frequency, which is the highest frequency of the original signal, anything beyond that, is considered to be noise (color blue).

Since the main purpose of this work is to characterize the basin's basement, the regional-residual separation removed all of the information below and on top of it. In that way, the spectral analysis found depths for the base of the basement $\left(Z_{b}\right)$ and for its top $\left(Z_{t}\right)$, along with its respectively errors $E_{b}$ and $E_{t}$, described on Table 1.

Tabel 1 - Depths of basement's base $\left(Z_{b}\right)$ and top $\left(Z_{t}\right)$ determined by spectral analysis, and its respectively errors $E_{b}$ and $E_{t}$.

\begin{tabular}{|l|c|c|c|c|}
\hline \multicolumn{5}{|c|}{ Results of the spectral analysis } \\
\hline Polygons & $\mathbf{Z}_{\mathbf{t}}(\mathbf{k m})$ & $\mathbf{Z}_{\mathbf{b}}(\mathbf{k m})$ & $\mathbf{E}_{\mathbf{t}}(\boldsymbol{\%})$ & $\mathbf{E}_{\mathbf{b}}(\boldsymbol{\%})$ \\
\hline $\mathbf{2 0 0} \mathbf{~ k m}^{\mathbf{2}}$ & -0.722 & -36.0 & 0.0025 & 0.121 \\
\hline $\mathbf{1 5 0} \mathbf{~ k m}^{\mathbf{2}}$ & -0.709 & -37.7 & 0.0024 & 0.116 \\
\hline $\mathbf{1 0 0} \mathbf{~ k m}^{\mathbf{2}}$ & -0.848 & -37.0 & 0.0055 & 0.132 \\
\hline $\mathbf{5 0} \mathbf{~ k m}^{\mathbf{2}}$ & -0.913 & -22.2 & 0.0132 & 0.075 \\
\hline $\mathbf{2 5} \mathbf{~ k m}^{\mathbf{2}}$ & -0.632 & -3.4 & 0.0062 & 0.014 \\
\hline
\end{tabular}



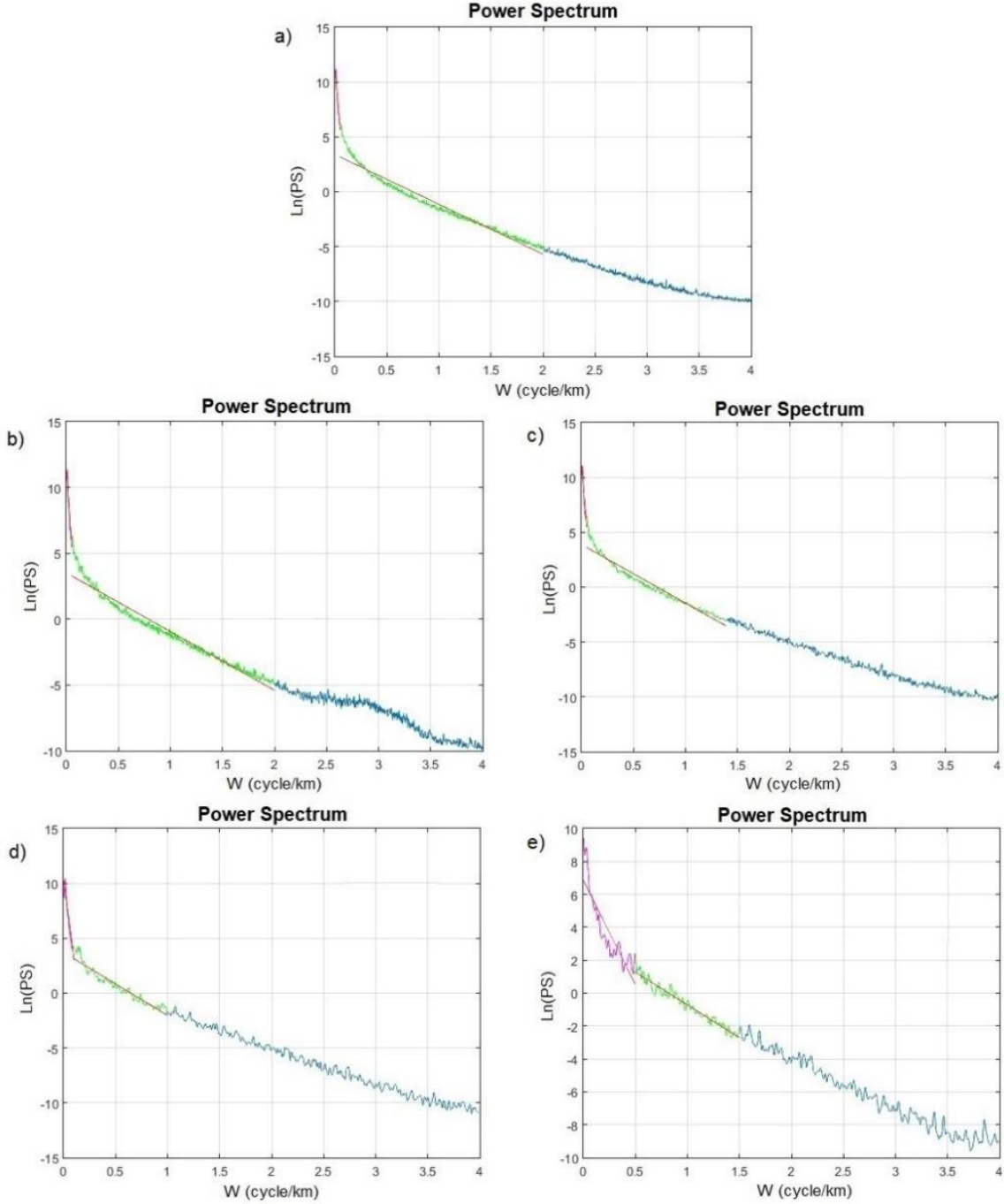

Figure 4 - Power spectrum for the polygons of: a) $200 \mathrm{~km}^{2}$; b) $150 \mathrm{~km}^{2}$; c) $100 \mathrm{~km}^{2}$; d) $50 \mathrm{~km}^{2}$ and e) $25 \mathrm{~km}^{2}$. The spectrum limits with the color magenta represents deep sources, the color green represents shallow sources and the color blue represents the noise of the data. The red line is the inclination (s) of the line Ln (PS) versus W (frequency). Source: Author (2020)

Since the greatest depth found for the basement's base was $37.7 \mathrm{~km}$, this was the depth chosen to carry out the regionalresidual separation. Information above 709 meters (depth of the

top) was also removed, because shallower sources were considered as noise. Thus, a Residual Magnetic Field Map (Figure 5.b) was obtained, where the profiles used to perform the magnetic inversion were extracted from, being the L1 and L2 referent to the Rio Coruripe Source, and L3 and L4 to the Pernambuco-Alagoas source. To determine the location of these profiles, the Total Horizontal Gradient (THG) was applied to the residual magnetic field data, which allowed better visualization of the source's edges, delimiting the contacts between the targets.

In the THG map (Figure 6), it was also possible to identify folds in the Rio Coruripe domain's region, due to its location at the northeast folding region of the Borborema Province. Contractional shear zones, such as the Belo Monte-Jeremoabo shear zone, indicated by the black triangles in Figure 6 , and a sinistral shear zone, indicated by the white arrows, located above the Pernambuco-Alagoas source, were also found in the locations previously shown in Figure 2.b. It's also possible to notice the presence of the Jirau do Ponciano gneissic dome, located below the Rio Coruripe source.

The magnetic lineaments seen in the THG map are accommodations of magnetic material, which locates in shallow surfaces, probably in the depths found by the spectral analysis in Tabel 1, above the basement $(\mathrm{Zt})$. These magnetic materials accommodate over shallower fault zones that are often controlled by the reactivation of basement faults. 

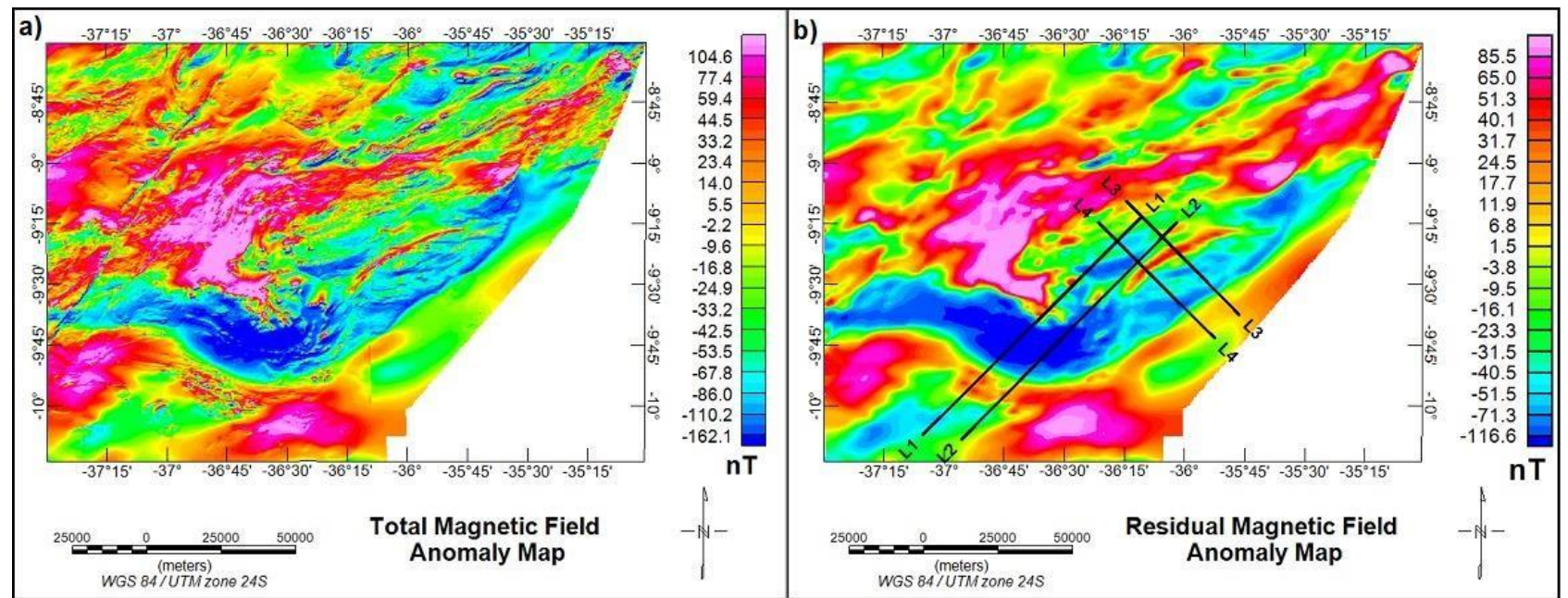

Figure 5 - a) Total magnetic field anomaly map; b) Residual magnetic field anomaly map, with profiles extracted for the magnetic inversion. L1 and L2 representing the Rio Coruripe source, L3 and L4 representing the Pernambuco-Alagoas source. Source: Author (2020).

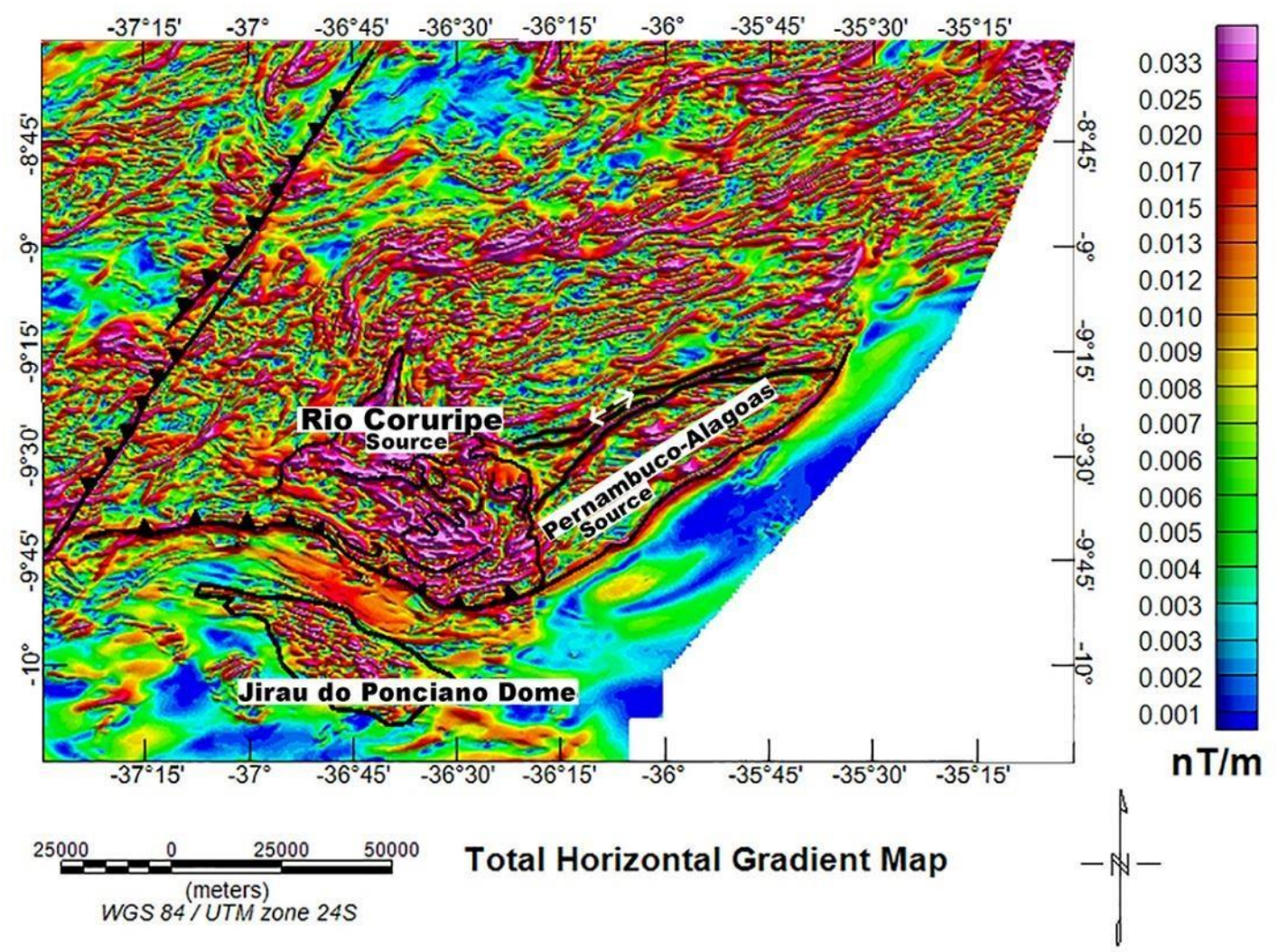

Figure 6 - Total horizontal gradient map, indicating lineaments correspondent to the sources, foldings in the Rio Coruripe domain, and black triangles and white arrows corresponding to the contractional and sinistral shear zones, respectively. Source: Author (2020). 
The THG map also allowed the interpretation of the source's strike-dip directions, where the Rio Coruripe source is at the NWSE direction, with a SW-NE dip direction and the PernambucoAlagoas source is at the NE-SW direction, with a SE-NW dip direction.

To perform the inversion, it was necessary to insert the entry parameters referent to the features of the earth's magnetic field of the time the data was obtained. The intensity of the magnetic field used was $25.380 \mathrm{nT}$, the field's inclination was $-27.3^{\circ}$ and its declination (magnetic north) was $-22.7^{\circ}$. These values were used for both the Rio Coruripe and Pernambuco-Alagoas sources' inversion.

The inversion is performed by inserting parameters related to the building of the prisms' matrix that will represent the subsurface, such as the number of prisms in the $\mathrm{X}$ (rows) and $\mathrm{Z}$ (columns) directions, and the thickness and susceptibility contrast for each prism. Since the inversion procedure is an optimization process, it was also necessary to insert a maximum number of iterations that the software will perform until the solution was stabilized. As a result, the software will deliver the depth and magnetic susceptibility of the prisms, which represents the sources in subsurface.

\subsection{Rio Coruripe Source}

For the inversion of the $\mathrm{L} 1$ profile referent to the Rio Coruripe source, 30 prisms were inserted along the $\mathrm{X}$-direction (rows) and 5 prisms were inserted along the Z-direction (columns), with a thickness of 6.000 meters for each prism. The maximum number of iterations was 20 , with a susceptibility contrast of 0.07 for each prism.

The result of the inversion for the L1 profile is shown in Figure 7, where a magnetic source, highlighted by the red rectangle drawn by hand, was found between 9.000 and 21.000 meters in depth, and its greatest lateral extension was found at 15.000 meters, with a magnetic susceptibility of 0.0055704 (SI). The error between the calculated and observed data was $4.48 \%$.
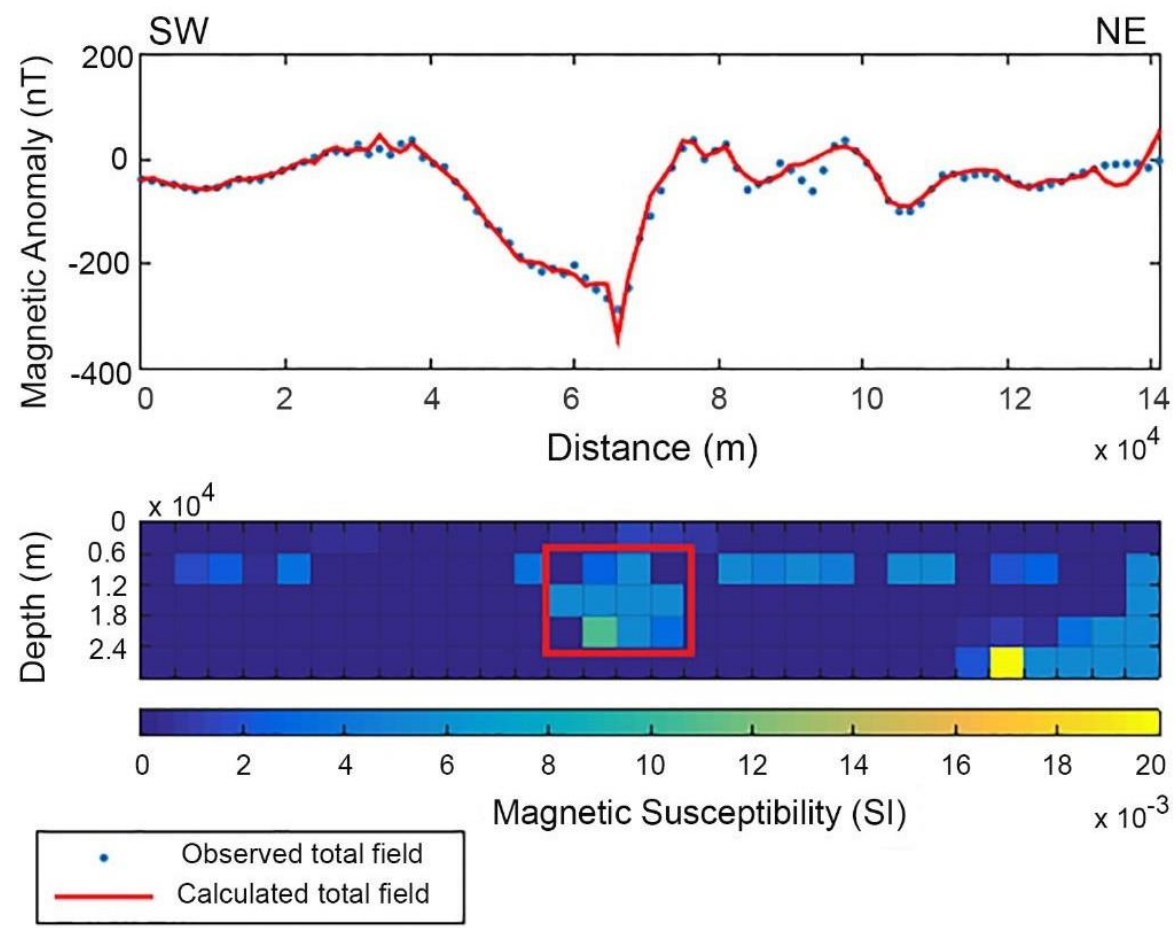

Figure 7 - Result of the magnetic inversion for the L1 profile, highlighting the Rio Coruripe source located between 9.000 and 21.000 meters. Source: Author (2020).

For the inversion of the $\mathrm{L} 2$ profile, also referent to the Rio Coruripe source, 30 prisms were inserted along the X-direction and 5 prisms were inserted along the Z-direction, with a thickness of 7.500 meters for each prism. The maximum number of iterations was also 20 , with a susceptibility contrast of 0.1 for each prism.

The result of the inversion for the $\mathrm{L} 2$ profile is shown in Figure 8, where the depth of the source was found between 11.250 and 18.750 meters, with a magnetic susceptibility of 0.0079577 (SI). The error between the calculated and observed data was $3.28 \%$.

In that way, we can assume that the Rio Coruripe source is located between 9.000 and 21.000 meters, where its superior and inferior boundaries are narrower and its lateral extension is located at 15.000 meters in depth. The source has an estimated magnetic susceptibility of approximately 0.0079 (SI) and 
outcrops into the surface, since we can see that there are prisms with a smaller magnetic susceptibility above the source in Figure 7 , that indicates that the source's magnetic susceptibility is smaller at the surface and enhances until the depth found by the inversion.
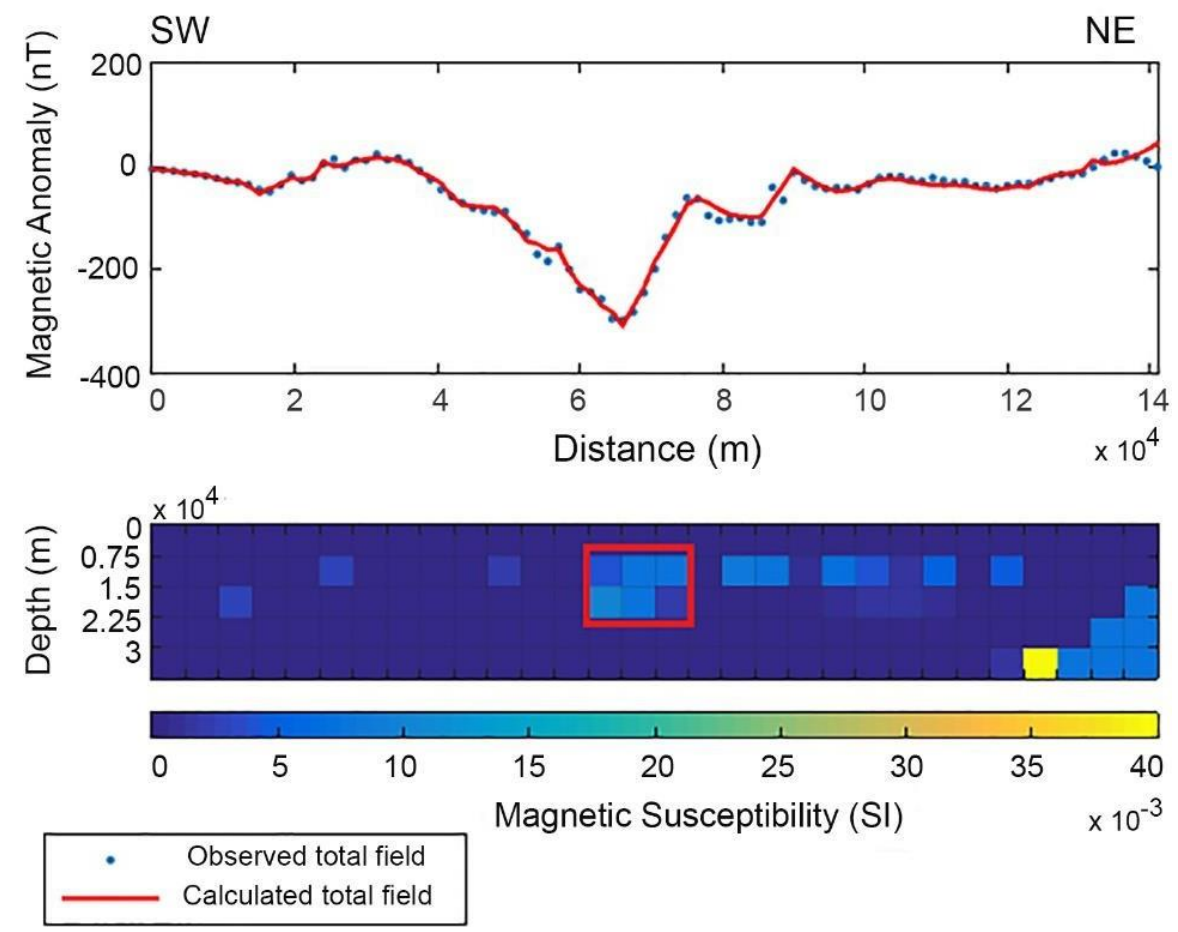

Figure 8 - Result of the magnetic inversion for the L2 profile, highlighting the Rio Coruripe source located between 11.250 and 18.750 meters. Source: Author (2020).

\subsection{Pernambuco-Alagoas Source}

For the inversion of the L3 profile referent to the Pernambuco-Alagoas source (Figure 9), 30 prisms were also inserted in the $\mathrm{X}$-direction and 5 prisms were inserted in the $\mathrm{Z}$ direction, with a thickness of 5.500 meters for each prism. The maximum number of iterations was 20 , with a susceptibility contrast of 0.1 for each prism.

The result of the inversion for the $\mathrm{L} 3$ profile shows a magnetic source, also highlighted by the red rectangle, found at approximately 7.500 meters in depth, with a magnetic susceptibility of 0.0079584 (SI). The error between the calculated and observed data was $5.02 \%$. The result also shows that the source has an approximate rectangular shape.

For the inversion of the $\mathrm{L} 4$ profile also referent to the Pernambuco-Alagoas source, 30 prisms were inserted along the $\mathrm{X}$-direction and 5 prisms were insert along the Z-direction, with a thickness of 6.000 meters and susceptibility contrast of 0.08 for each prism. The maximum number of iterations was also 20 .

The result of the inversion for the L4 profile is shown in Figure 10, where a magnetic source was found at 9.000 meters in depth, with a magnetic susceptibility of 0.0076 (SI). The error between the calculated and observed data was $4.04 \%$.

Thus, we can assume that the Pernambuco-Alagoas source is located between 7.500 and 9.000 meters in depth, being shallower than the Rio Coruripe source and with a rectangular shape, and has a magnetic susceptibility of approximately 0.0076 (SI). The Pernambuco-Alagoas source also outcrops into the surface, since we can also see that there are prisms with a smaller magnetic susceptibility above the source in Figures 9 and 10, that also indicates an enhancement of magnetic susceptibility until the depth found by the inversion. 

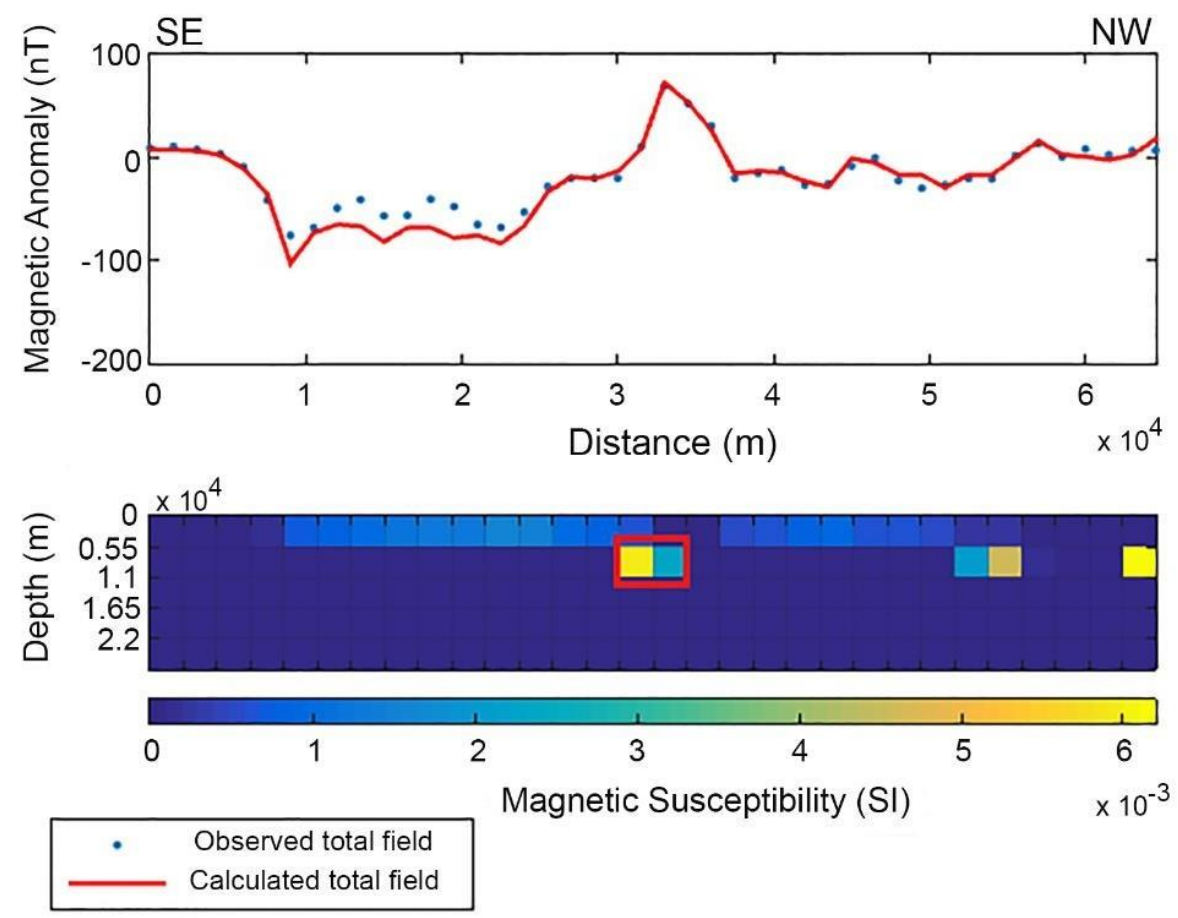

Figure 9 - Result of the magnetic inversion for the L3 profile, highlighting the Pernambuco-Alagoas source located at 7.500 meters. Source: Author (2020).
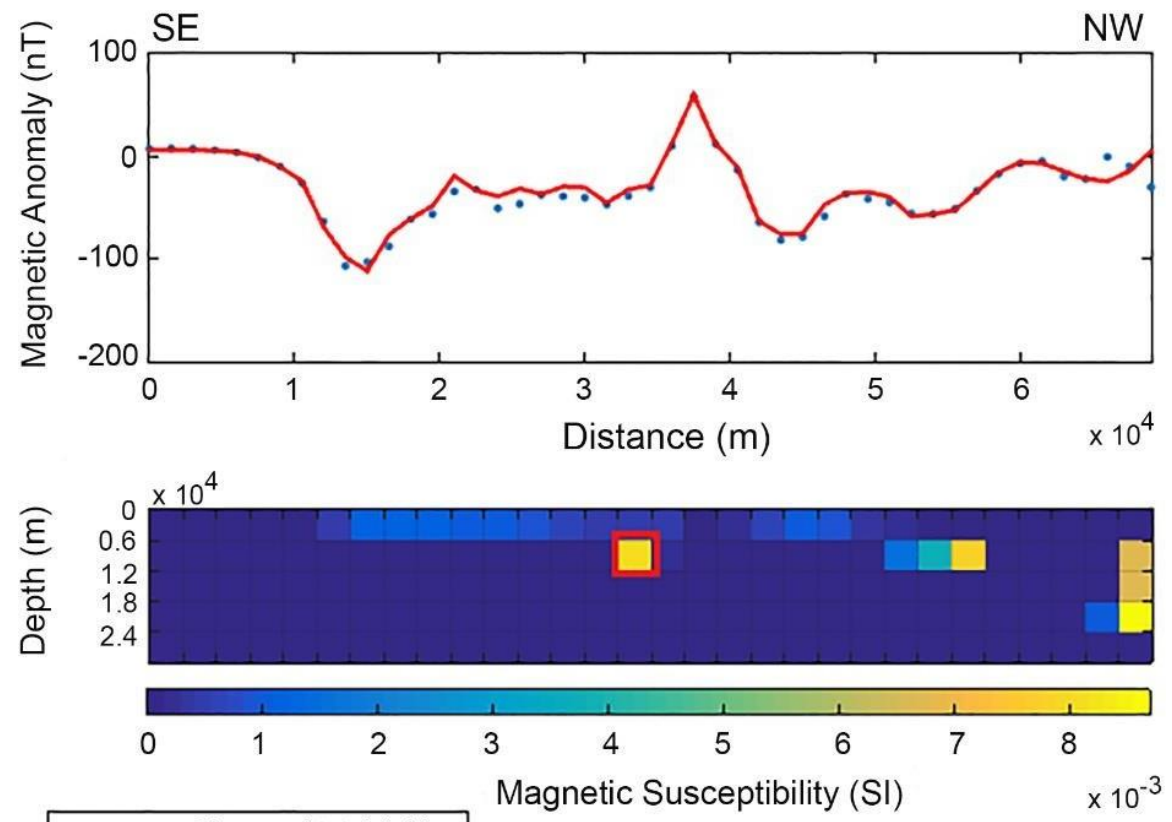

Figure 10 - Result of the magnetic inversion for the L4 profile, highlighting the Pernambuco-Alagoas source located at 9.000 meters. Source: Author (2020). 


\subsection{Gravity Modelling}

To verify the information obtained in the magnetic inversion's results, gravity models were created, where the lithologies inserted were obtained according to the ones that outcrops in the region. The gravity data were acquired by the Nacional Agency of Petroleum (ANP) and the GEOTERM SE-AL project, in which this work was developed, with a survey of 450 gravity stations.

The profiles used for the gravity models were extracted from the Residual Bouguer Anomaly Map, shown in Figure 11, where the L1 (Rio Coruripe source) and L3 (Pernambuco-Alagoas source) profiles are located in the same positions of the profiles used for the magnetic inversion shown in Figure 5.b.

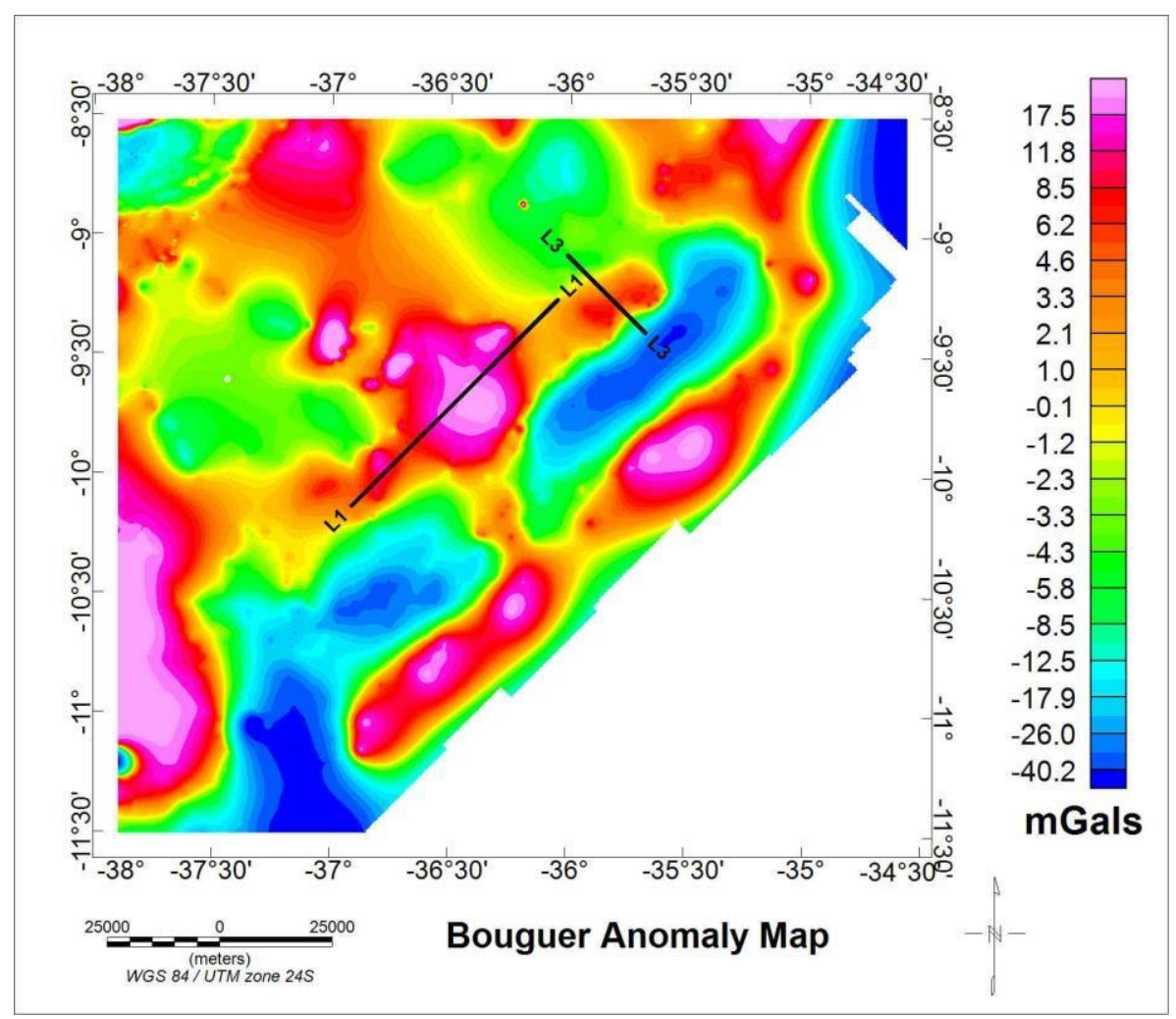

Figure 11 - Residual bouguer anomaly map, with the profiles extracted for the gravity models. L1 and L3 representing the Rio Coruripe and Pernambuco-Alagoas sources, respectively. Source: Author (2020).

Since the Rio Coruripe domain is formed by paragneisses and its basement is formed by granulite and amphibolite facies, the densities used were: paragneisses $-2.80 \mathrm{~g} / \mathrm{cm}^{3}$; granulite -2.65 $\mathrm{g} / \mathrm{cm}^{3}$; amphibolite $-2.70 \mathrm{~g} / \mathrm{cm}^{3}$; sediments $-2.30 \mathrm{~g} / \mathrm{cm}^{3}$.

In the gravity model shown in Figure 12, we can see that the Rio Coruripe source (a paragneiss) outcrops into the surface, with its narrower part at approximately 9.000 meters, its biggest lateral extension at approximately 15.000 meters and goes back to straighten again between 18.000 and 21.000 meters, which are the results found for this source's magnetic inversion.

We can also see that the basement base was located at approximately $37.7 \mathrm{~km}$ and the sediments (shallower sources, that were previously considered as noise) goes down to approximately 709 meters, where the basement top is located, which are the results found by the spectral analysis.

The Jirau do Ponciano dome was also modelled since the gravity profile passes on top of it, with a density of $2.8 \mathrm{~g} / \mathrm{cm}^{3}$.
The error between the observed and calculated data in the gravity model for the $\mathrm{L} 1$ profile is $0.385 \%$.

Since the Pernambuco-Alagoas domain is formed by orthogneisses and high degree supracrustal units (granulite) intercalated by granites, the densities used for this source's gravity model were: orthogneiss $-2.80 \mathrm{~g} / \mathrm{cm}^{3}$; granite -2.70 $\mathrm{g} / \mathrm{cm}^{3}$; granulite $-2.65 \mathrm{~g} / \mathrm{cm}^{3}$; sediments $-2.30 \mathrm{~g} / \mathrm{cm}^{3}$.

The Pernambuco-Alagoas source (an orthogneiss) outcrops into the surface, has a rectangular shape and is located between 7.500 and 9.000 meters in depth, as detected by the magnetic inversion (Figure 13). The error between the observed and calculated data in the gravity model for the L3 profile is $0.232 \%$. The basement's base and top are located in the same depths found by the spectral analysis, although in some parts, the sediments go to a depth deeper than 709 meters, due to the fact that the L3 profile passes through a part of the sedimentary basin. 


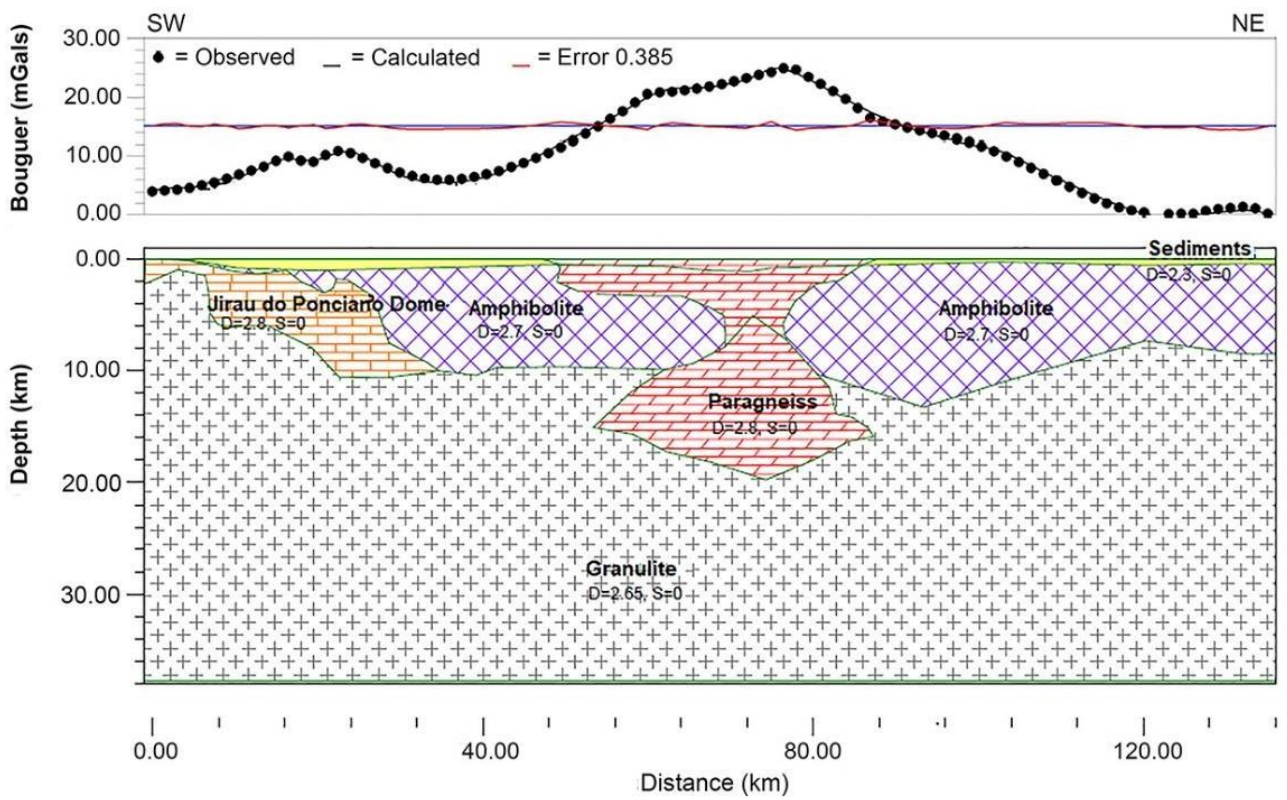

Figure 12 - Gravity model of the L1 profile for the Rio Coruripe source, represented by the paragneiss outcropping into the surface. The Jirau do Ponciano Dome is also modelled. Source: Author (2020).

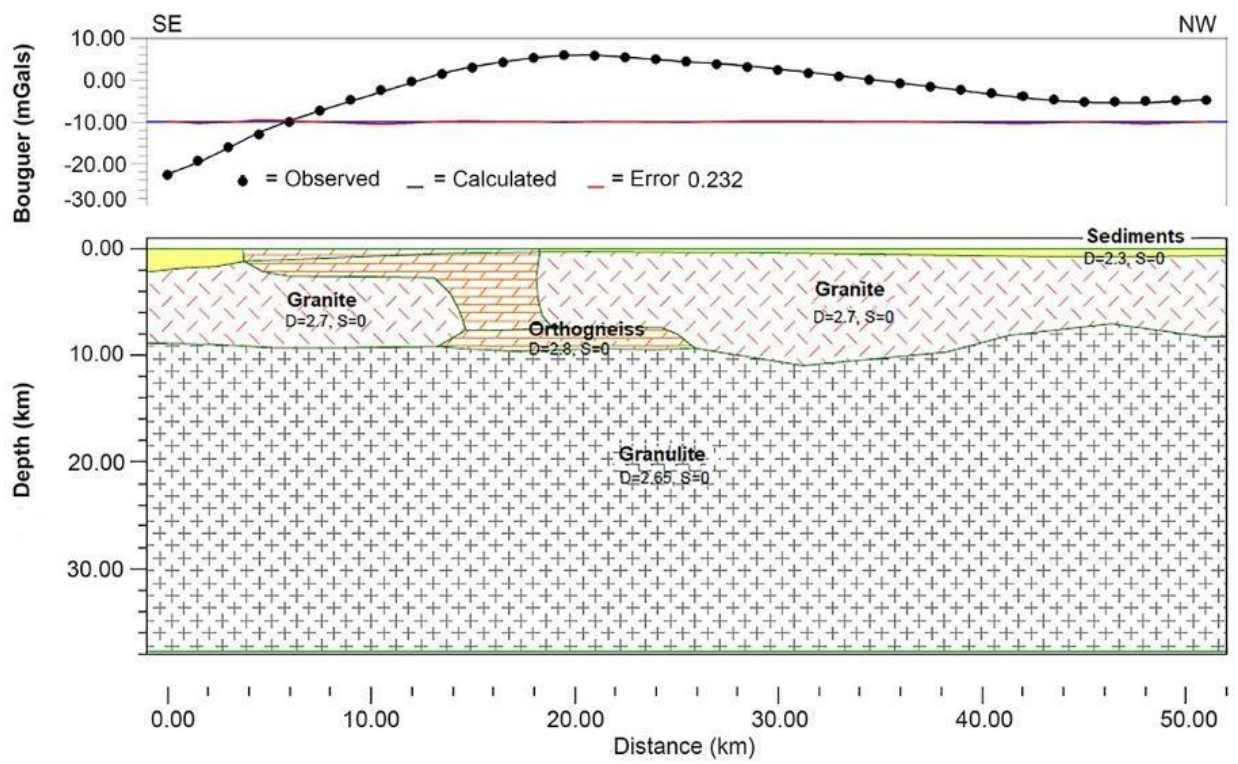

Figure 13 - Gravity model of the L3 profile for the Pernambuco-Alagoas source, represented by the orthogneiss outcropping into the surface. Source: Author (2020)

\section{DISCUSSIONS}

Analyzing the results of the magnetic inversion and the gravity modellings for the Rio Coruripe and the PernambucoAlagoas sources, and knowing that the Sergipano Folding Belt represents an orogenic belt formed during the brasiliano cycle (Almeida et al., 1977), the continental collision and plate subduction that generated this belt might also be responsible for the foldings in the Rio Coruripe domain and the contractional shear zones located in this region that we were able to find in Figure 6. Also, this geological event possibly pushed part of the Rio Coruripe source under the Pernambuco-Alagoas source, which can justify the depths found by the magnetic inversion, since the second one ends at 9.000 meters and the first one begins at the samedepth. 


\section{FINAL CONSIDERATIONS}

The results of the magnetic inversions, main purpose of this work, were satisfactory, since the calculated data obtained by it were well adjusted to the observed data. For the Rio Coruripe source, the inversion detected a body with a magnetic susceptibility of approximately 0.0079 (SI) between 9.000 and 21.000 meters in depth and that outcrops into the surface with a smaller magnetic susceptibility. In the Pernambuco-Alagoas domain, the inversion detected a source with a magnetic susceptibility of approximately 0.0077 (SI) between 7.500 and 9.000 meters in depth and that also outcrops into the surface with a smaller magnetic susceptibility.

The spectral analysis was of extreme importance for this work, because it was able to find a depth for the basement base and top, which are located at $37.7 \mathrm{~km}$ and 709 meters, respectively. The interpretation of the THG map was useful, because it provided geological information that helped understanding the location and directions of the sources, folds and shear zones in the region.

All of these results were verified by the gravity models created, which located all the depths found by the magnetic inversion and spectral analysis. In that way, we were able to produce a geological interpretation that helped understand the tectonic environment in the basement adjacent to the SergipeAlagoas basin.

The magnetic inversion obtained susceptibility contrasts in each cell and, with this, delineated the geometry of the true sources. The basement's relief characterized in the gravity models allowed to explain the distribution of magnetic susceptibility in depth inside the continental crust, as well as the accommodation of magnetic material in important lineaments at shallower surfaces.

Finally, we were able to understand that the foldings and shear zones located in the region are possibly related to the continental collision that originated the Sergipano Folding Belt, which also made the Rio Coruripe source be partially pushed under the Pernambuco-Alagoas source, affecting the structure of the basement.

\section{REFERÊNCIAS}

ALMEIDA, F.D., HASUI, Y., BRITO NEVES, B.D., FUCK, R. Províncias estruturais brasileiras. Simpósio de Geologia do Nordeste 8, 1977. 363-391.

ANP, Agência Nacional do Petróleo, G.N.e.B. Sumário geológico e setores em oferta: Bacia de Sergipe-Alagoas $\left(13^{a}\right.$ rodada de licitações). Disponível em: http://www.anp.gov.br/. Acesso em: 20/08/2018.

BRITO NEVES, B.D., SIAL, A., RAND, H., MANSO, V. The Pernambuco-Alagoas massif, northeastern Brazil. Revista Brasileira de Geociências, vol. 12, 240-250, 1982.

LAST, B., KUBIK, K. Compact gravity inversion. Geophysics vol. 48, 713-721, 1983.

LIMA, H.M., SANTOS, L.C.M.D.L., DOS SANTOS, E.J. Transeção geológica ao longo da porção oriental da Província Borborema, NE do Brasil. Relatório Técnico Projeto Geoterm (SE-AL), 2015.
MENDES, V.A., LIMA, M.A.B., DE MORAIS, D.M.F., DE BRITO, M.D.F.L. Geologia e Recursos Mineiras do Estado de Alagoas. CPRM - Serviço Geológico do Brasil. Ministério de Minas e Energia. Secretaria de Minas e Metalurgia, 2017. 113p.

NEVES, S.P., DA SILVA, J.M.R., BRUGUIER, O. The transition zone between the Pernambuco-Alagoas domain and the Sergipano Belt (Borborema Province, NE Brazil): Geochronological constraints on the ages of deposition, tectonic setting and metamorphism of metasedimentary rocks. Journal of South American Earth Sciences vol. 72, 266-278, 2016.

DOS SANTOS, R.A., MARTINS, A.A.M., DAS NEVES, J.P., LEAL, R.A. Geologia e Recursos Mineiras do Estado de Sergipe. CPRM - Serviço Geológico do Brasil. Ministério de Minas e Energia. Secretaria de Minas e Metalurgia, 1998. 99p.

SOUZA-LIMA, W., ANDRADE, E.D.J., BENGTSON, P., GALM, P. A bacia de sergipe-alagoas: evolução geológica, estratigráfica e conteúdo fóssil. Aracaju: Fundação Paleontológica Phoenix , 1-34, 2002.

STOCCO, S., GODIO, A., SAMBUELLI, L. Modelling and compact inversion of magnetic data: A Matlab code. Computers \& Geosciences vol. 35, 2111-2118, 2009.

TALWANI, M., WORZEL, J.L., LANDISMAN, M. Rapid gravity computations for two-dimensional bodies with application to the mendocino submarine fracture zone. Journal of geophysical research vol. 64, 49-59, 1959.

\section{ACKNOWLEDGEMENTS}

We acknowledge Geotec-Cenpes-Petrobras for financial support of this research, along with the GEOTERM SE-AL project, in which this work was developed; The Company of Research in Mineral Resources (CPRM) and the Brazilian National Agency of Petroleum, Natural Gas and Biofuels (ANP) for providing the geophysical data used in this re- search; and CPGG and LFNA (Federal University of Bahia) for the permission to use their laboratories.

Received in: 13/08/2019

Accepted for publication in: 05/05/2020 